Л. А. Воронова

КЗ «Дніпропетровський спеціалізований клінічний медичний иентр матері та дитини імені проф. М. Ф. Руднєва»

\title{
ВИЯВЛЕННЯ ЛІДЕРСЬКИХ ЯКОСТЕЙ СЕРЕД СТАРШИХ МЕДИЧНИХ СЕСТЕР
}

\section{Виявлення лідерських якостей серед старших медичних сестер}

\section{л. А. Воронова}

КЗ «Дніпропетровський спеціалізований клінічний медичний центр матері та дитини імені профр. М. Ф. Руднєва»

Резюме. Нагальна необхідність реформування системи охорони здоров'я України потребує якісно нового підходу до управління як на державному рівні, так і на рівні закладу охорони здоров'я

Мета дослідження - проаналізувати контингент старших медичних сестер з точки зору оцінки лідерських якостей та підготовленості в питаннях організації та управління в системі охорони здоров'я.

Матеріали і методи. У дослідженні взяли участь 25 старших медичних сестер комунального закладу «Дніпропетровський спеціалізований клінічний медичний чентр матері та дитини імені проф. М. Ф. Руднєва» Дніпропетровської обласної ради», які відповіли на запитання розробленого нами опитувальника.

Результати. При максимально можливій сумі балів, що дорівнює 250, сумарний середній бал був 180,32ะ4,06, що свідчить про необхідність більш ірунтовної підготовки реальних і потенційних керівників із різних аспектів менеджменту. Їх позиції $є$ досить сильними у відносинах із вищим керівництвом у питаннях стратегічного управління, в цілому позитивній оцінці інновацій, у глибоких знаннях профресійних питань, а також в тому, що вони високо цінують колективи, в яких працюють. У той же час не завжди у них є досить чіткі критерії для оцінки якостей конкретних співробітників; вони явно не повністю довіряють і не завжди радяться з колективом, з одного боку, $і$, з іншого, недостатньо чітко контролюють його роботу.

Висновки. Розвиток лідерських якостей старших медичних сестер $є$ запорукою підвищення ефрективності управління сестринським персоналом.

Ключові слова: старша медична сестра; лідер.

\section{ВСТУП}

Нагальна необхідність реформування системи охорони здоров'я України потребує якісно нового підходу до управління як на державному рівні, так і на рівні закладу охорони здоров'я. Кваліфрікаційний рівень керівників охорони здоров'я відіграє
Identification of leadership qualities among senior nurses

\section{A. Voronova}

Dnipropetrovsk Specialized Clinical Medical Center of Mother and Child named after Prof. M. F. Rudnev

$$
\text { e-mail:_voronova_l@tdmu.edu.ua }
$$

Summary. The urgent need to reform Ukraine's health care system requires a qualitatively new approach to governance at both the state and health care levels.

The aim of the study - to analyze the contingent of senior nurses in terms of assessment of leadership qualities and training in the organization and management of the health care system.

Materials and Methods. The study involved 25 senior nurses of the municipal institution "Dnipropetrovsk Specialized Clinical Medical Center of Mother and Child named after Prof. M. F. Rudnev" Dnipropetrovsk Regional Council", who answered the questions of our questionnaire.

Results. With the maximum possible amount of points equal to 250, the total average score was (180.32 44.06), which indicates the need for more thorough training of real and potential managers in various aspects of management. Their positions are quite strong in relations with senior management, in matters of strategic management, in general a positive assessment of innovation, in-depth knowledge of professional issues, as well as in the fact that they highly value the teams in which they work. At the same time, they do not always have clear enough criteria for assessing the qualities of specific employees; they clearly do not fully trust and do not always consult with the team, on the one hand, and, on the other hand, do not clearly control its work.

Conclusions. The development of leadership skills of senior nurses is the key to improving the efficiency of nursing staff management.

Key words: senior nurse; leader.

значну роль у процесі перебудови галузі й слугує запорукою успішності та ефективності модернізації, оскільки сучасна охорона здоров'я неможлива без організуючого начала, носієм якого є керівна ланка системи [1].

У сучасних умовах системи охорони здоров'я 
настав час організувати роботу сестринського персоналу відповідно до вимог реформування системи охорони здоров'я [2, 3]. Поліпшення якості надання медичних послуг населенню здебільшого залежить від рівня підготовки медичних кадрів, раціонального використання кадрового потенціалу та реорганізації системи планування для здійснення запланованої роботи. В умовах медичної реформи старшим медичним сестрам як ніколи важливо здобувати та поліпшувати лідерські якості [4-6]. На практиці ми стикаємося 3 тим, що деякі керівники не мають лідерських навичок, до того ж виходячи 3 індивідуально-типологічних рис особистості, зародки таких рис у них взагалі відсутні. Тому використовуючи метод «проб і помилок» або омани, вони вчаться на практиці. Але такі методи роботи застарілі, ще гірше - вони можуть мати негативні наслідки [7].

Метою дослідження було проаналізувати контингент старших медичних сестер 3 точки зору оцінки лідерських якостей та підготовленості в питаннях організації та управління в системі охорони здоров'я.

\section{МАТЕРІАЛИ I МЕТОДИ}

У дослідженні взяли участь 25 старших медичних сестер комунального закладу «Дніпропетровський спеціалізований клінічний медичний центр матері та дитини імені профр. М. Ф. Руднєва» Дніпропетровської обласної ради».

Для аналізу контингенту старших медичних сестер з точки зору оцінки лідерських якостей та підготовленості в питаннях організації та управління у системі охорони здоров'я було розроблено опитувальник.

\section{Частина I}

1. Ваш стаж роботи на посаді:

- менше 1 року;

- від 1 до 5 років;

- від 5 до 10 років;

- більше 10 років

2. Чи погоджуєтесь Ви, що процес забезпечення високої якості сестринських послуг нерозривно пов'язаний із процесом контролю й оцінки діяльності сестринського персоналу?

- так, пов'язаний;

- пов'язаний опосередковано;

- ні, не пов'язаний

3. Чи погоджуєтесь Ви, що процес контролю й оцінки діяльності потребує систематизації і вироблення єдиних методичних підходів?

- так, це необхідно;

- ні, в цьому немає необхідності;

- так, і в нашому закладі розроблена система контролю
4.Чи відомі Вам методики оцінки якості діяльності сестринського персоналу?

- так, відомі;

- ні, не відомі

5. Якщо на попереднє питання Ви відповіли «Так», то чи вважаєте Ви якусь із описаних у літературі методик оцінки якості діяльності сестринського персоналу достатньо об'єктивною і такою, що охоплює всі рівні й напрямки діяльності сестринської служби:

- впевнений (на), що таких методик немає;

- не знаю;

- так, мені відомі такі методики

6. У випадку появи науково обґрунтованої системи контролю й оцінки якості діяльності сестринського персоналу, чи готові Ви імплементувати її у Вашому закладі:

- безумовно, так;

- так, якщо вона буде достатньо простою і структурованою;

- лише якщо цього буде вимагати керівництво

7. Чи імплементовані у Вашому закладі внутрішні стандарти (методичні рекомендації, інструкції, протоколи і т. д.) проведення сестринських маніпуляцій:

- так, по всіх маніпуляціях;

- так, по деяких маніпуляціях;

- $\mathrm{Hi}$

8. Оцініть значимість (ранжуйте за ступенем важливості: 1 - найбільш важливі, 3 - найменш важливі) ресурсів для забезпечення якісного надання сестринської допомоги:

- кадрові;

- матеріально-технічні;

- інфрормаційні

9. Яким, на Ваш погляд, може бути допустимий масштаб відхилень при оцінці виконання стратегічної програми розвитку (розрахованої на 3-5 років) сестринської справи:

- до $10 \%$;

- до $20 \%$;

- до $30 \%$;

- інше

10. Який відсоток укомплектованості сестринських ставок фрізичними особами, на Ваш погляд, $€$ мінімально допустимим для забезпечення якісного виконання сестринським персоналом своїх обов'язків:

$\%$

11. Якою, на Ваш погляд, повинна бути оптимальна кількість медичних сестер із квалісрікаційною категорією зі стажем роботи до 5 років:

$$
\%
$$

12. Якою, на Ваш погляд, повинна бути оптимальна кількість медичних сестер із кваліфрікаційною категорією зі стажем роботи від 5 до 10 років: $\%$ 
13. Якою, на Ваш погляд, повинна бути оптимальна кількість медичних сестер із кваліфікаційною категорією зі стажем роботи більше 10 років: $\%$

14. Як, на Ваш погляд, найбільш раціонально має розподілятися робочий час старшої медичної сестри стаціонару (при 8-годинному робочому дні):

- організаційна робота;

- контроль за підлеглими;

- навчання, інструктаж підлеглих;

- робота з документацією;

• інші види робіт

15. Як, на Ваш погляд, найбільш раціонально має розподілятися робочий час палатної медичної сестри стаціонару (при 8-годинному робочому дні):

- виконання лікарських призначень;

- догляд за пацієнтами;

- діяльність щодо забезпечення санітарно-епідеміологічного режиму;

- робота з документацією;

- інші види робіт

16. Як, на Ваш погляд, найбільш раціонально має розподілятися робочий час перев'язувальної медичної сестри стаціонару (при 8-годинному робочому дні):

- виконання лікарських призначень;

- діяльність щодо забезпечення санітарно-епідеміологічного режиму;

- робота з документацією;

- інші види робіт

17. Як часто, на Ваш погляд, має проводитись експертна оцінка діяльності кожної медичної сестри стаціонару:

- 1 раз в місяць;

- 1 раз на 3 місяці;

- 1 раз на 6 місяців;

- 1 раз в рік;

- лише у відповідь на скарги пацієнтів

18. Ким, на Ваш погляд, повинна проводитись експертна оцінка діяльності медичних сестер:

- старшою медичною сестрою відділення;

- замісником головного лікаря з роботи із сестринським персоналом, головною медсестрою;

- комісією із декількох спеціалістів

19. Оцініть за 5-бальною шкалою вагомість нижчеперерахованих фракторів (від 1 до 5) при проведенні оцінки діяльності медичних сестер відділень:

- санітарно-епідеміологічне благополуччя відділення;

- якість догляду за пацієнтами;

- якість виконання лікарських призначень;

- якість ведення документації;

- дотримання правил роботи з медикаментами;

- матеріально-технічне оснащення;

- укомплектованість сестринських ставок фрізичними особами;
- кількість кваліфрікаційних категорій у медичних сестер відділення;

- рівень знань медичних сестер відділення, виявлених при проведенні контролю (тестування, залік, співбесіда);

- думка пацієнтів про роботу медичних сестер відділення;

- думка лікарів про роботу медичних сестер відділення;

- кількість ускладнень, пов'язаних із неякісною роботою медичних сестер;

- організація праці медичних сестер;

- інсрормаційно-методичне забезпечення діяльності медичних сестер (наявність на робочих місцях методичних рекомендацій, стандартів, інструкцій, протоколів)

20. Яким чином, на Ваш погляд, отримувати вірогідну інсрормацію про оцінку пацієнтами якості роботи сестринського персоналу:

- шляхом аналізу скарг та подяк пацієнтів;

- шляхом безпосереднього спілкування з пацієнтами при проведенні адміністративних обходів;

- шляхом регулярного проведення анонімних письмових опитувань пацієнтів;

• інше

бали: а) 10; б) 5; в) 2

\section{Частина II}

1. Виконати для Вас розпорядження керівника:

а) не викликає труднощів;

б) важко;

в) неможливо

2. Чи завжди чітко Ви уявляєте мету виконуваної роботи:

а) завжди;

б) іноді;

в) не уявляю

3. За що Ви цінуєте своїх підлеглих:

а) за минулі заслуги;

б) за високий професіоналізм;

в) за комунікабельність

4. Як часто Вам не вистачає витримки:

а) завжди витримана з підлеглими;

б) іноді;

в) часто

5. Ваше ставлення до конфрліктів на роботі:

a) вони неминучі;

б) ви їх миттєво «гасите»;

в) не допускаєте взагалі

6. Виконуючи свої функкціональні обов'язки, Ви потребуєте

підтримки інших членів колективу:
а) завжди;
б) іноді;
в) ніколи

7. Ви вважаєте необхідним брати участь у суспільному житті колективу:
а) обов'язково; 
б) не проявляючи ініціативу;

в) не обов'язково

8. Ви часто затримуєтеся на роботі:

а) часто;

б) рідко;

в) ніколи

9. У Вашому колективі проблеми прогнозуються:

а) прогнозуються;

б) з'являються несподівано;

в) не виникають

10. Проблеми, що виникають, Ви вирішуєте:

а) негайно;

б) після роздумів;

в) намагаєтеся «утікти» від рішення

11. У складній ситуації Ви скористаєтеся допомогою:

а) членів колективу;

б) звернетеся до керівництва;

в) спробуєте вирішити проблему самостійно

12. Відношення членів вашого колективу до якості виконуваної роботи:

а) прагнуть виконати свою роботу якісно;

б) індисрерентно;

в) якість роботи їх не цікавить

13. Оцінку якості роботи членів Вашого колективу необхідно проводити:

а) на кожному зібранні;

б) іноді;

в) у разі необхідності

14. Роботу над «помилками» необхідно проводити:

а) на загальних зборах;

б) індивідуально;

в) не проводити взагалі

15. Повсюдна комп'ютеризація Вас:

а) тішить;

б) викликає невпевненість;

в) лякає

16. Часта зміна обладнання викликає у Вас:

а) інтерес до усього нового;

б) необхідність у додатковому навчанні;

в) складнощі в освоєнні

17. Проведення зборів колективу повинно бути:

а) регулярно;

б) іноді;

в) у міру необхідності

18. Якість виконуваної роботи Вашими співробітниками Ви оцінюєте:

а) регулярно;

б) в критичних ситуаціях;

в) ніколи

19. Кожен співробітник повинен володіти усіма вузькоспеціалізованими методиками вашого підрозділу:

а) обов'язково;

б) тільки той, хто цим займається; в) бажано в міру необхідності

20. Для підвищення профресіоналізму співробітників необхідно:

а) курси підвищення квалісрікації;

б) курс лекцій на робочому місці;

в) удосконалення на робочому місці

21. Як Ви вважаєте, чи потрібно керівнику володіти усіма складними і спеціалізованими методиками:
а) безсумнівно;
б) у міру можливості;
в) необов'язково

22.Чи намагаєтесь Ви аналізувати виконану за день роботу:
а) обов'язково;
б) іноді;
в) проводжу аналіз

23. Часто Ви стикаєтеся з проблемами, які не в змозі вирішити самостійно:

а) досить часто;

б) такі ситуації неминучі;

в) усі проблеми намагаюся вирішити сама

24. До кого Ви звертаєтеся за допомогою:

а) керівництва;

б) досвідчених співробітників;

в) намагаюся знайти вихід 3 положення сама

25. Для кращої організації роботи підрозділу Вам необхідно розширення повноважень:

а) в межах компетенції;

б) необхідності;

в) так не вважаю.

\section{РЕЗУЛЬТАТИ Й ОБГОВОРЕННЯ}

На запитання, чи можуть вони надихати колектив на високоефективну роботу трохи більше половини (56,0 \%) опитаних - 14 осіб відповіли позитивно. Негативно при цьому відповіли 28,0 \% респондентів (7 осіб). Питома вага осіб, що сумнівалися, склала 16,0 \% (4 особи).

На запитання про те, чи пояснюють респонденти свою позицію співробітникам, які не згодні 3 ними у вирішенні тих чи інших питань, негативно відповіли 16,0%, позитивно відповіли 84,0 \% (21особа).

На питання про те, чи викликає складнощі необхідність виконання розпоряджень керівника, переважно (у 96,0 \% випадків - 24 особи) респонденти відповіли, що ніяких складнощів у них при цьому не виникає (певні складнощі були лише в 1 особи (4,0 \% респондентів). Середній бал був $9,84 \pm 0,05$.

Для будь-якого керівника досить важливо мати стратегічне мислення, тобто чітко уявляти цілі планованої і виконуваної роботи. В основному $(92,0$ \% випадків) респонденти орієнтувалися в цілях, але 2 особи (8,0 \%) відповіли, що так буває не завжди. Середній бал був 9,52ะ0,12. 
При реалізації кадрового менеджменту одним із найважливіших і досить складних напрямків $€$ оцінка кожного з працівників з урахуванням усієї сукупності його характеристик. Респондентам необхідно було виділити критерії оцінки працівників, яким вони віддають перевагу при оцінці персоналу: наявні заслуги, рівень професіоналізму, ступінь комунікабельності. У 72,0% (18 осіб) випадків було виділено такий критерій як професіоналізм, у 20,0 \% (5 осіб) - комунікабельність, у 8 \% (2 особи) - наявні заслуги. Середній бал за даним критерієм був $5,02 \pm 0,12$.

Важливою характеристикою керівника $є$ вміння тримати себе в руках, у тому числі при спілкуванні з підлеглими. Проведене опитування показало, що велика частина старших медичних сестер може володіти собою при роботі з середнім медичним персоналом. Так 28,0 \% (7 осіб) респондентів завжди витримані з підлеглими; 60,0 \% респондентів (15 осіб) іноді не вистачає витримки, а 8,0 \% (2

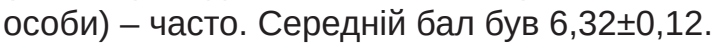

У будь-якій профресійній діяльності в силу як об'єктивних, так і суб'єктивних причин неминучим $€$ виникнення конфрліктних ситуацій, яким керівник повинен, за можливості, запобігти, а при появі правильно вирішити. Аналіз ставлення респондентів до конолліктів показав, що більша половина 15 осіб (60,0 \%) з них вважає конолікти в колективі неминучими; 7 осіб (28,0 \%) опитаних відмітили, що виникаючі консрлікти миттєво «гасять» і лише 3 особи (12,0 \%) - не допускають їх виникнення взагалі. По даному блоку середній бал виявився достатньо високим і склав 7,93 00,24.

Відповіді, дані старшими медичними сестрами на наступне питання, характеризували переваги того, чи іншого стилю управління, до якого вони тяжіють.

Так, при прийнятті управлінського рішення i, особливо під час його реалізації, 8,0 \% респондентів (2 особи) обов'язково спираються на підтримку колективу; 76,0 \% опитаних (19 осіб) так поступають лише іноді, а 16,0 \% (4 особи) старших медсестер усі питання, пов'язані з виконанням своїх фрункціональних обов'язків, вирішують виключно одноосібно. 3 огляду на розподіл відповідей зрозуміло, що середній бал виявився невисоким $(4,51 \pm 0,11)$.

Встановленню тісніших (неформальних) відносин серед співробітників сприяє участь керівника у громадській роботі колективу. Проведене опитування показало, що більшість опитаних (80 \% - 20 осіб) вважає для себе обов'язковою участь у громадському житті колективу; 16,0 \% (4 особи) можуть брати участь, не проявляючи самостійно такої ініціативи; а 4,0 \% (1 особа) не вважають таку діяльність обов'язковою. В цілому середній бал був достатньо високим $(8,9 \pm 0,24)$.
Хоча, як відомо, робота керівника характеризується, крім іншого, ненормованим робочим днем, часті затримки на роботі характеризують його не кращим чином. Тих, хто затримується на роботі часто, виявилося трохи більше третини (40,0\% 10 осіб); 60,0 \% (15 осіб) затримуються рідко. Се-

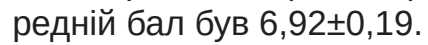

Хорошому керівнику властиво попереджати, прогнозувати можливість і своєчасно вирішувати ті чи інші проблеми в колективі. На фракт прогнозування проблем вказали 16,0 \% опитаних (4 особи). Для 72,0 \% (18 осіб) вони 3'являються несподівано, а 12,0 \% (3 особи) вважали, що у них в колективах проблеми відсутні (середній бал склав $5,88 \pm 0,19)$. При цьому негайно вирішують виниклі проблеми 36,0 \% (9 осіб) респондентів; після певних роздумів - 60,0 \% (15 осіб), а 4 \% (1 особа) відзначили, що намагаються уникнути їх вирішен-

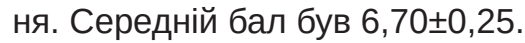

Причому 72,0% (18 осіб) опитаних вважали, що неминучими $є$ ситуації, коли проблеми виявляються для керівника нерозв'язними самостійно, а 4,0 \% (1 особа) вважали, що такі ситуації виникали доволі часто. І лише 24,0% (6 осіб) проблеми намагаються вирішити самостійно. Середній бал ви-

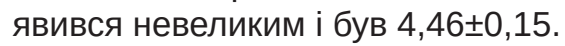

При виникненні таких проблем 32,0% (8 осіб) респондентів звертаються до керівництва; 56,0 \% (14 осіб) - користуються допомогою і підтримкою досвідчених працівників; 12,0 \% (3 особи) вирішу-

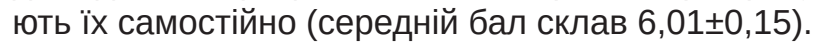

Про відсутність тісної взаємодії із колективом свідчить той фракт, що менше половини (40,0 \% 10 осіб) опитаних зазначила, що вдаються до його допомоги при виникненні складної ситуації; 48,0 \% (12 осіб) вважають, що краще в цих випадках апелювати до керівництва, а 12,0 \% (3 особи) вирішують ситуацію, що склалася самостійно. Середній

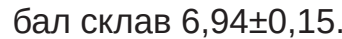

Незважаючи на вищевказане, в цілому опитані досить високо оцінюють свої колективи. Так, 92,0 \% 3 них вважають, що працівники завжди намагаються робити свою роботу якісно, і лише 2 особи (8 \%) оцінили ставлення співробітників до роботи як ін-

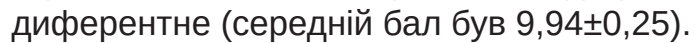

Для того, щоб управлінські рішення були більш ефективними, необхідно приділяти належну увагу оцінці якості виконуваної колективом роботи. На жаль, не всі опитані належною мірою усвідомлюють необхідність оперативного контролю. Лише 24,0 \% (6 осіб) вважали, що оцінку якості роботи співробітників колективу необхідно проводити періодично (на кожних зборах); 12,0 \% (3 особи) вважали, що оцінку якості роботи співробітників колективу можна проводити іноді, а більшість - 16 осіб (64,0 \%) вважали, що тільки в разі потреби (серед-

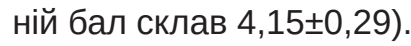


Більша частина (56,0 \%) - 14 осіб опитаних відзначила, що регулярно оцінюють якість виконаної роботи колективу в цілому; 32,0 \% (8 осіб) роблять це іноді, а 12,0 \% (3 особи) - лише в міру необхід-

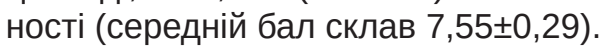

Важливим розділом роботи керівника $€$ аналіз роботи, який повинен здійснюватися щодня, для оперативного коректування плану на наступний день, оцінки ефективності використання робочого часу і прогнозування складних ситуацій або проблем, що можуть виникнути в колективі. Більша частина респондентів (72,0\%) - 18 осіб прагнула до щоденного аналізу виконаної роботи; 24,0 \% (6 осіб) робили це іноді, а 4,0 \% (1 особа) практично

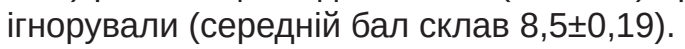

При виявленні помилок, яких припустилися працівники, з'ясовувати їх, на думку більшості (88,0 \% - 22 особи) респондентів, необхідно індивідуально, і тільки 12,0 \% - 4 особи дотримувалися протилежної точки зору (середній бал склав $5,55 \pm 0,21)$.

Неоднозначним $є$ ставлення респондентів і до впровадження (зміни) нового обладнання. Лише у половини (52,0 \% - 13 осіб) з них будь-яке нове викликає інтерес; 40,0 \% - бачать при цьому проблему подолання, а 8,0 \% - додаткові складнощі (середній бал був $7,46 \pm 0,21)$.

Однією з важливих фрункцій менеджменту є координація роботи колективу. Стосовно теми даного дослідження можна відзначити, що в основному (72,0 \% - 18 осіб) респондентів вважали, що кожен із співробітників їх підрозділів повинен володіти усіма вузькоспеціалізованими методиками; 16,0 \% більше схилялися до цієї точки зору, але вважали це бажаним, щоб використовувати в разі необхідності; а 12,0 \% (3 особи) вважали це прерогативою окремих конкретних співробітників (середній бал

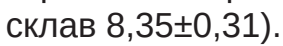

Не було у старших медичних сестер і однозначної думки про те, яким чином необхідно підвищувати профеесійний рівень своїх співробітників. Половина (52,0 \% - 13 осіб) вважала, що це потрібно робити на курсах підвищення квалісрікації; 28,0 \% (7 осіб) - шляхом читання лекцій за місцем роботи; 20,0 \% (5 осіб) - шляхом удосконалення на робочому місці (середній бал склав $6,85 \pm 0,31$ ).

Часто для роз'яснення нюансів складних і особливо нових, спеціалізованих методик працівники звертаються до керівника, тому ми поставили питання про необхідність володіння старшою медсестрою новими спеціалізованими методиками. Більшість (88,0 \% - 22 особи) респондентів були впевнені у цьому; 12,0 \% - вважали це бажаним у

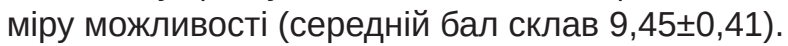

Для керівника (так само як і для будь-якого співробітника) важливо чітко уявляти собі коло своїх прав і обов'язків (повноважень) та, в ідеалі, на своєму рівні управління керівнику повинно вистачати даних йому повноважень для вирішення поставлених завдань. У реальності більшість $(80,0 \%)$ опитаних вважала, що можна було б розширити наявні повноваження, але в рамках компетенції керівника; 9,0 \% вважали, що даних їм повноважень явно недостатньо; повністю задоволені ситуацією, що склалася, були 11,0 \% опитаних (се-

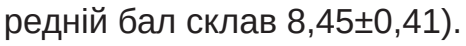

Процедура контролю якості сестринської допомоги - одна 3 найважливіших фрункцій управління якістю, що $є$ новим напрямом у діяльності сестринських служб. Керівники сестринських служб зможуть успішно реалізувати такий вид діяльності тільки в тому випадку, якщо будуть розроблені відповідні методи контролю й оцінки, системи показників, що характеризують якість сестринської допомоги, за різними сестринськими спеціальностями [8]. Тільки профресіоналізм керівників середнього медичного персоналу може охарактеризувати діяльність співробітника, відобразити здатність успішно вирішувати проблеми, спираючись на досвід, набуті знання, навички, опановану методологію. Але в більшості випадків недостатньо високий рівень просресіоналізму керівника негативно впливає на професіоналізм підпорядкованого персоналу, а відповідно на основі їхньої спільної праці - й на морально-психологічний клімат у колективі. Тому головна/старша медична сестра повинна відігравати провідну роль у моральному вихованні всіх членів колективу, в дотриманні етичних норм медичними працівниками. А головне соціальне завдання керівників середнього та молодшого медичного персоналу - створити в колективі взаємини між людьми, що забезпечить умови для збереження психічного здоров'я співробітників та підвищення ефрективності праці $[9,10]$.

\section{ВИСНОВКИ}

При максимально можливій сумі балів, що дорівнює 250, сумарний середній бал склав 180,32 44,06, що свідчить про необхідність більш ґрунтовної підготовки реальних і потенційних керівників із різних аспектів менеджменту. Їх позиції $\epsilon$ досить сильними у відносинах із вищим керівництвом, у питаннях стратегічного управління, в цілому позитивній оцінці інновацій, в глибоких знаннях професійних питань, а також в тому, що вони високо цінують колективи, в яких працюють.

У той же час не завжди у них $є$ досить чіткі критерії для оцінки якостей конкретних співробітників; вони явно не повністю довіряють і не завжди радяться з колективом, з одного боку, і, з іншого, недостатньо чітко контролюють його роботу. Це $є$ резервом для підвищення ефективності управління сестринським персоналом, і сприяло б запобіганню і своєчасному усуненню помилок, попередженню або швидкому вирішенню багатьох проблем. 


\section{СПИСОК ЛІТЕРАТУРИ}

1. Лехан В. М. Соціально-психологічний портрет керівників закладів охорони здоров'я: сучасний стан і тенденції змін / В.М.Лехан, Л.В.Крячкова, Г. С. Канюка // Україна. Здоров'я нації. - 2015.- № 3. - С.75-81.

2. Scott P. A. What is nursing in the 21st century and what does the 21st century health system require of nursing? / P. A. Scott, A. Matthews, M. Kirwan // Nursing Philosophy. - 2013. - Vol. 15 (1). - P. 23-34.

3. Goodare P. Literature review: Why do we continue to lose our nurses? Australian journal of advanced nursing. 2017. - Vol. 34 (4). - P. 50-56.

4. Федик Т. Як розбудити у собі лідера: експрес-курс головної медсестри / Т. Федик // Довідник головної медичної сестри. - 2018. - № 2. - С.47-51.

5. Опыт организации контроля качества сестринской деятельности в терапевтическом стационаре / В. В. Масляков, В. А. Левина, И. В. Романова, Н. М. Не-

\section{REFERENCES}

1. Lekhan VM, Kryachkova LV, Kanyuka HS. [Social and psychological portrait of managers of health facilities: current state and trends]. Ukraina. Zdorovia natsii. 2015;3: 75-81. Ukrainian.

2. Scott PA, Matthews A, Kirwan M. What is nursing in the 21st century and what does the 21st century health system require of nursing? Nursing Philosophy. 2013;15(1): 23-34.

3. Goodare P. Literature review: Why do we continue to lose our nurses? Australian Journal of Advanced Nursing. 2017;34(4): 50-6.

4. Fedyk T. [How to wake up a leader: an express course of the head nurse]. Dovidnyk holovnoi medychnoi sestry. 2018;2: 47-51. Ukrainian.

5. Maslyakov VV, Levina VA, Romanova IV, Reluctant NM. [Experience in organizing quality control of nursing activities хотящая // Фундаментальные исследования. - 2013. № 9-3. - C. 404-408.

6. Cherian S. Review on leadership in nursing / S. Cherian, S. Karkada // International Journal of Nursing Research and Practice. - 2017. - Vol. 4 (1). - P. 58-66.

7. Гришняєва О. В. Лідерство в медсестринстві як складова швидкої адаптації до роботи в лікувально-просрілактичних закладах / О. В. Гришняєва // Медична психологія. - 2018. - № 3. - 42-45.

8. Перепадя О. В. Методичні підходи до оцінки якості сестринської допомоги / О. В. Перепадя // Актуальні проблеми клінічної та профрілактичної медицини. - 2018. - T. 2, № 4. - C. 25-32.

9. Абашник Н. М. Роль медичної сестри в Україні та у світі/ Н. М. Абашник // Медсестринство. - 2019. - № 4. - С. 7-10.

10. Петрущак О. М. Роль медичної сестри на сучасному етапі розвитку охорони здоров'я / О. М. Петрущак, І. Я. Криницька // Медсестринство. - 2017. - № 4. - С. 48-50.

in a therapeutic hospital]. Fundamentalnyye issledovaniya. 2013;9-3: 404-8. Russian.

6. Cherian S, \& Karkada S. Review on leadership in nursing. International Journal of Nursing Research and Practice. 2017;4(1): 58-66.

7. Hryshnyayeva O. V. [Leadership in nursing as a component of rapid adaptation to work in treatment and prevention facilities]. Medychna psykholohiia. 2018;3: 42-5. Ukrainian.

8. Perepadya OV. [Methodical approaches to assessing the quality of nursing care]. Aktualni problemy klinichnoi ta profilaktychnoi medytsyny. 2018; 2(4): 25-32. Ukrainian.

9. Abashnyk NM. [The role of the nurse in Ukraine and in the world]. Medsestrynstvo. 2019;4: 7-10. Ukrainian.

10. Petrushchak OM, Krynytska IYa. [The role of the nurse in the current stage of development of health care]. Medsestrynstvo. 2017;4: 48-50. Ukrainian. 